\title{
Sovereignty and Regional Integration in Latin America: A Political
}

Paulo Roberto de Almeida**

\section{A Latin American Quandary: National Sovereignty and Regional Integration}

\begin{abstract}
The two terms, sovereignty and regional integration, are indeed a quandary for decision-makers: if they intend to preserve national sovereignty they should not engage in any process of economic integration; conversely, if they are open to proceeding with the opening of economies and reciprocal trade liberalization with selected part-

\footnotetext{
* Article submitted on October 2nd, 2013 and approved for publication in November 1st, 2013.

** Paulo Roberto de Almeida is a career diplomat, Ph.D. In Social Sciences (University of Brussels, 1984), and professor of International Political Economy at the graduate studies in Law of the University Center of Brasilia (Uniceub). Deputy Editor of Revista Brasileira de Política Internacional, has many published works in international relations, diplomatic history, foreign policy of Brazil and integration (www.pralmeida.org). E-mail: pralmeida@mac.com.
}

CONTEXTO INTERNACIONAL Rio de Janeiro, vol. 35, n² 2, julho/dezembro 2013, p. 471-495. 
ners, they have to renounce the most important levers of exclusive sovereignty over certain public policies.

There is a contradiction between these two terms, either in general, or in some specific cases in particular. Western Europe, for instance, could only establish the bases of its regional integration process long ago in 1950, because its two most important countries, France and Germany, chose to relinquish their respective sovereignties over the two most important factors of war: coal and iron. And Latin America, or especially South America, which constitutes the core subject matter of this essay, has not advanced to any successful or significant scheme of economic integration precisely because two of its most important countries, Brazil and Argentina, have never relinquished an inch of sovereignty over their most basic economic policies, namely in the macroeconomic sector - that is, fiscal, exchange, and monetary policies - and in the sectorial realm, industrial and trade policies in particular.

Latin America has a long history in the juridical tradition of preserving national sovereignty, and also in the devising of special mechanisms to defend and enforce it, either in the domestic sphere, or through international law. In fact, the principle and the political fact of national sovereignty is as old as the system of mutual recognition of sovereign states established by the Peace of Westphalia of 1648 . Since then, national sovereignty has been developing conceptually, as well as through the practices of modern states. In its contemporary form, the concept appears in a consolidated form in the UN Charter (1945), which, despite its alleged coverage of with the "peoples of the United Nations", is entirely respectful of the rights of its member states, which are totally sovereign in matters of internal politics (Chapter 1, articles 1 and 2 of the Charter).

Despite being established as a principle in international law, sovereignty was never respected by the big powers in their colonialist and 
imperialist initiatives throughout the ages. This is, perhaps, one of the reasons why it constituted a main tenet of the juridical thinking developed in Latin America since the early $19^{\text {th }}$ century. Threats of European intervention after the new independence of the Iberian American States, British economic hegemony over the entire continent and its meddling in political conflicts on many occasions, and the rise of the United States as a dominant power at the end of that century, are factors that explain the development by Latin American jurists of new concepts arising from the old Westphalia principle. The strict adherence to national sovereignty was one of them, to be enshrined in a "juridical theology" which is responsible, in most cases, for the slow march of various schemes of regional integration in the continent.

\section{The Calvo Doctrine in its Historical Context: The Droit des Gens in 19th Century}

This doctrine was notably put forward by the Argentine diplomat and legal scholar Carlos Calvo, in his acclaimed work on international law, published in Paris in 1868. The question was raised in connection with unpaid debts or indemnities of Latin American states vis-à-vis foreign lenders, and the legal treatment of the resulting conflicts. The goal was to defend the interests of the indebted governments which were facing possible judicial prosecution in creditor countries or, worse, open diplomatic intervention, which could be as harsh as armed punitive expeditions (usually by gunboats). The so-called Calvo doctrine suggested that debt contracts should include a clause stating the competence of national courts to settle conflicts arising from possible claims in case of default. ${ }^{1}$

Much later, following retaliatory measures adopted by some European powers against the defaulting government of Venezuela, the 
Argentine foreign minister, Luis María Drago, proposed in 1902 a follow-up to the Calvo doctrine, proclaiming the illegality of the use of force, or armed intervention, in cases involving public debt. In doing so, he invoked the Monroe doctrine, proclaimed eighty years earlier by the American president in order to prevent any European intervention in hemispheric affairs. Incidentally, Monroe's 1823 proclamation to the American Congress was supported by Great Britain, which at that time was interested in barring the old colonial powers or the Holy Alliance from any attempt at new colonization in the Americas.

Later on, Latin American countries became alarmed, not only by the real or supposed European threats, but also by the actual and growing use of force by the United States against surrounding neighbors in the Caribbean and Central America, practices that started even before the Spanish-American war of 1898 . Victory in that war by the United States resulted in the independence of $\mathrm{Cuba}$, which was followed by the 1910 Platt Amendment to its 1902 Constitution, representing, thereafter, the subjection of the Caribbean island to a kind of American guardianship or semi-protectorate.

\section{The Roosevelt Corollary and its Political Consequence: The Drago Principle}

At that time, the United States was in fact engaged in a substantial revision of the Monroe doctrine, as president Theodore Roosevelt intended to reserve for his own country the right of intervention in Latin American affairs. Despite confirming adherence to the Monroe doctrine, Roosevelt, in his December 1904 message to the Congress, declared that "chronic wrongdoing" by neighboring countries - which could mean unwillingness to "pay [its] obligations" - might "require intervention by some civilized nation", thus forcing the United Sta- 
tes, "however reluctantly, in flagrant cases of such wrongdoing or impotence, to the exercise of an international police power."

This had the effect of reinforcing the adherence of Latin American countries to the Drago principle, which was largely reflected in the 1906 Pan-American Conference of Rio de Janeiro, where most Latin American countries sided with the thesis of the Argentine foreign minister. That is, they all requested from the United States a firm, legal and written commitment to not interfere in their internal affairs. However, the Big Brother from North America was not yet prepared to fully endorse the principle of non-intervention, as required by his Latin American neighbors.

Brazil tried to mend the fences. There were political reasons for Brazil to adhere to a modified, American version of the Drago doctrine. One of these reasons was the desire of the then Minister of Foreign Affairs, Baron Rio-Branco, to establish a joint arrangement with the United States to rule over the entire Western hemisphere, in a kind of 'unwritten alliance'. 3 Though aware of Brazilian limitations, at a juncture when Argentina was the richest country in Latin America, Rio Branco sensed the need to establish a fraternal relationship with the United States, the giant of the North in order to manage the lingering animosity of neighboring countries toward the giant of the South.

\section{Brazil's Defense of Sovereignty at the Second Hague Peace Conference, 1907}

The subject was raised again at the Second Hague Peace Conference, in 1907, where the questions of debt collection by states and the ensuing Drago doctrine on non-intervention, as well as the non-use of force, were raised again. This occurred against a background of virtual 
opposition between, on one side, the European diplomats and the U.S. delegation, defending the right of intervention as proposed by the American general Horace Porter, and, on the other side, the "Drago doctrine countries", adamantly opposed to any infringement of the national sovereignty principle. At that conference, Brazil, considering itself to be a 'good debtor', kept a middle-course stance, trying at the same time to placate its neighbors' fears, and to adopt an accommodating position toward the American and European view.

In a speech delivered in July 23, 1907, the Brazilian head of delegation, the eminent jurist Ruy Barbosa, explained the official position as follows: "The intervention of the three powers against Venezuela received no approval from anyone among us. (...) We do not deny the obligation to repay... But, some consider that they will not be obliged to comply, unless, under their own advice, they have the means to do so. In this case, however, there is no juridical obligation, but solely a moral duty. (...) This is not the theory of the sovereign right; this is sovereign abuse. If applied to the domestic life of the States, it would abolish the legal order, and it would do the same if applied to international relations. (...) What the American proposal does is to reduce international conflicts regarding debts of foreign states to the common right of compulsory arbitration. It does not repeal, providing the arbitration ends in failure, the legitimacy of the appeal to coercive means to support the right of the creditors" (TRINDADE, 1986, p. 48-51).

Notwithstanding its intention to reconcile the use of force against debtors with the appeal to compulsory arbitration to settle disputes over external debt, the Brazilian delegation could not join other countries in the adoption of a modified version of the Drago doctrine, in the form adopted as the Porter (Second) Convention on the Limitation of the Employment of Force for the Recovery of Contract Debts. The objection was more of a procedural than substantive nature, as Brazil had some qualms about the functioning of an arbitration 
system under the hegemony of great powers (and their dominance over the selection of judges).

Article 1 of the said Convention stated that the Contracting Powers "agree not to have recourse to armed force for the recovery of contract debts claimed from the Government of one country by the Government of another country as being due to its nationals." But it also stated, right afterwards, that "This undertaking is, however, not applicable when the debtor State refuses or neglects to reply to an offer of arbitration, or, after accepting the offer, prevents any compromise from being agreed on, or, after the arbitration, fails to submit to the award.",

In the end, out of the fourteen conventions negotiated at The Hague, Brazil did not sign the second one - dealing with the collection of contracted debts - nor the twelfth - establishing an International Compensation Court. In fact, Brazil only agreed to the first convention, creating the Permanent Court of Arbitration, after a clarification of the absolute equality of sovereign states and the designation of its judges (MESSAGE..., 1978, p. 613-615). The Brazilian refusal was explicitly linked with the absolute principle of sovereign equality of all states, but the Brazilian jurists were always trying to strike a balance between the rights and duties of every state.

At the Third Inter-American Conference of Rio de Janeiro, in 1906, an International Commission of Jurists was created, with representatives from almost all American countries. Its work was mainly directed toward the codification of international law (for both the public and private sectors), which was to guide relations among its member states. After a series of sub-commission workshops and other specialized regional meetings, in the various capitals of the Hemisphere, its prolific work was consolidated in various inter-American treaties or conventions adopted at the Havana conference of 1928, dealing with: the Status of Aliens, Treaties, Diplomatic Officers, Consular Agents, 
Maritime Neutrality, Asylum, Duties and Rights of States in the Event of Civil Strife, and Extradition (this last one at the Montevideo conference, in 1933). With respect to private international law, their work produced an entire code, named the Bustamante Code, which is still valid. ${ }^{5}$

\section{National Sovereignty as a Defense against American Interventionism}

Up to that juncture, that is, the beginning of the 1930s, pursuant to the spirit and the practice of the Roosevelt Corollary, the American government was very reluctant to recognize as legitimate the demands from Latin American countries for assurances of non-intervention in their internal affairs from their biggest hemispheric neighbor. At most, Washington started to sign with its neighbors and many other countries a series of 'pacifist treaties' conceived by Secretary of State William Jennings Bryan (1913-1915), by which the U.S. only agreed to solve by peaceful means conflicts arising with other states, either by direct negotiations between the parties or by means of arbitration.

The guarantees sought by Latin American countries were only formally given - but just as unilateral declarations, not in the form of a legally binding treaty - when president Franklin Delano Roosevelt proclaimed the so-called 'Good Neighbor Policy', beginning in 1933 under Secretary of State Cordell Hull. But this new orientation in American policy for the region was guided much more by the U.S. intention of preventing foreign intrusion by the Nazi-Fascist powers of Germany and Italy in the region, than by the desire to please Latin American countries.

The Second World War and its aftermath for Latin America saw a deepening of those potential trends: the Chapultepec Conference in 1945, the 1947 Petropolis conference with the signing of Inter-American Assistance Treaty (one of the conceptual bases for the collecti- 
ve security mechanism of the North Atlantic Treaty Organization), and the subsequent foundation of the Organization of the American States at the 1948 Bogota Conference. All those elements confirmed the natural preeminence of U.S. hegemony in the region, also amplifying the fear of Latin American countries of too much interference of the Big Brother in their internal affairs. Indeed, the Cold War atmosphere justified new concerns for the preservation of national sovereignty of Latin American states against the encroachments of the Big Brother, and the successive military coups, as an apparent materialization of these tendencies, only served to confirm those fears.

At the same time, European integration was being launched among the six pioneer states of the Coal and Steel Community, which was transformed, in 1957, into a common market undertaking, thus encouraging similar projects among Latin American countries. In Europe, there was an explicit renouncement of national sovereignty, represented by the High Authority of the Paris Treaty of 1957, and by the Council and the Commission created by the 1957 Rome treaties. In Latin American, however, national states were not prepared to go so far; thus, successive diplomatic instruments establishing integration schemes, among them the Montevideo treaties of 1960 and 1980, creating, respectively, the Latin American Free Trade Association and the Latin American Integration Association, only provided for economic cooperation between like-minded states to perform the limited opening up of reciprocal trade, giving no authority whatsoever to any supranational body or council of representatives.

\section{Institutional Arrangements in Latin American Integration and the Issue of Sovereignty}

Many analysts of the regional integration processes in Europe and in Latin America are profoundly influenced by the institutional archi- 
tecture of European schemes and tend to consider Latin American experiences against the same framework. In so doing, they establish the same distinction between, on the one hand, supranational institutions embodied in the Community law, and, on the other hand, free trade arrangements or the customs unions undertakings that adopt mere intergovernmental mechanisms. The explanation for the failure of various Latin American experiments is, in this way, attributed to the attachment that most states in the region demonstrate for the principle of national sovereignty. By extension, and as a result, the implicit conclusion is that the intergovernmental nature of those experiments is the main factor that has hindered their "natural evolution" towards a kind of nec plus ultra of the regional integration processes, represented by the European model and its respective institutional framework.

Is there, in fact, an institutional dichotomy that could explain the success of one experiment, on the European side, and the failure of the other, on the Latin American side? One preliminary comment, concerning methodology, is that this "causal correlation" is never subjected to empirical research, which would examine the actual processes developed through concrete policies, and their objective results, in various processes of integration; rather, is merely a conceptual argument, derived from abstract judgments made on the basis of hypothetical models of integration. In "retrospect", the failure of the Latin American experiments serve as "proof" of the inadequacy of the intergovernmental scheme, while the European success is shown as a demonstration of the clear suitability of the supranational model. The culprit, in this kind of analysis, is in the organizational form of the integration process, that is, in their decision-making institutions.

The bias implicit in this kind of analysis is that the institutional framework adopted in one case or another is capable of determining the "command and control" of the actual processes, or their success or failure, irrespective of real determinants in the economic and politi- 
cal domains. Another assumption is that supranational arrangements, more or less independent of the members' governments, are superior in nature, due to some assumed high quality of the community law, in face of the intergovernmental schemes; institutions formally located "above" the states could be presumably more "rational" and focused solely on integration goals, than national governments, which receive pressures from their domestic action groups and prospective losers in the process.

The issue here is the overestimation of the institutional aspect - including in its purely abstract or conceptual form - over the hard elements of the integration process. The real question to be tackled by any honest observer of the integration process in Latin America must be this one: what is more relevant in a genuine endeavor for economic integration, which presupposes the dismantling of political and technical barriers to trade and to the free flow of production factors, of goods and services between the members of the bloc? The answer can not be more evident: it is the mutual opening in itself and by itself, irrespective of the institutional architecture in place; all practical measures must be put in place to achieve the main objective of the integration process. Without this reciprocal dismantling of barriers among the members of the bloc, there is no real integration, whatever the political features formally adopted in signed agreements. Irrespective of the political structure, and of the nature of the decision-making process, in any concrete experiment, if there is no renouncing to some degree of national political sovereignty over (at least parts of) macroeconomic policies and some sectorial policies (especially industry, trade, and agriculture), it is unlikely that a real integration process can thoroughly succeed.

It is the real reciprocal opening, and the elimination of obstacles to the free flow of goods, services and production factors, that is, the most important exchanges between the members of a bloc, that constitute the core and matter, and the substantive legitimization of any 
integration scheme; without those elements, the process would be devoid of any real content, even with some sophisticated political arrangements. The institutional envelope represents a set of tools and mechanisms serving to guide and manage the process, able also to define the decision-making structure and the dispute settlement system, between states and, or between private parties; it is relevant, even crucial, but must not be considered the essence, in itself, of the integration process, because the same goals - reciprocal opening and real liberalization - can be achieved by different institutional tools and mechanisms.

In short, there is nothing inherently detrimental to an integration process if its management is placed under the supervision of diplomats and other government officials, instead of being conducted by the bureaucrats of a supranational structure. In any case, the true core of an integration process is the effective liberalization and reciprocal opening, in every sector of practical consequences for that process, not the formal dispositions of a treaty (which in Latin America is, sometimes, just that: a formal disposition). One historical hypothesis that cannot be tested nowadays posits that the European process of integration could have been achieved through an intergovernmental architecture, that is, in the absence of supranational institutions: the example of Benelux, a successful experiment prior to the deepening of the (then) Community, after union, offer in that respect some space for speculation (and, indeed, MERCOSUR is much more modeled on the Benelux treaty than on the Rome instruments). Conversely, in the case of some Latin American experiments - especially in the case of MERCOSUR - even more ambitious commitments, such as a common market undertaking (which was also the objective of the Andean Community), probably might not be attained even within the framework of supranational institutions, that is, community law arrangements, like the European model, if the national governments could not commit themselves with the dismantling of the most im- 
portant barriers to total integration; they have always failed to live up to the treaties they have formally signed. So, the problem is not the instrument, it is the national governments.

\section{Is there a Real Opposition between Supranational and Intergovernmental Models?}

Analysts dealing with the integration schemes in Latin America usually call attention to the opposition between these two models - the intergovernmental and the supranational - that serve as a framework for the institutional arrangements being put into practice in those regional experiments. From a theoretical standpoint, the distinction can make some sense, and both models are always presented in the textbooks dealing with the law of integration; from a practical point of view, however, the distinction is less clear as to its concrete implications for the tasks of trade liberalization and reciprocal economic opening. The reason is that the institutional possibilities of a defined architecture to guide the process of integration are multiple, ranging from a wide spectrum of political arrangements suitable to accommodating different economic situations and actual conditions of the member countries or partners in such a scheme (which, incidentally, is only vaguely defined at an operating level).

Article 24 of the original GATT (1947) and its interpretation or clarification in successive protocols and decisions by the multilateral trade system - Part IV of the GATT, in 1964, and the Enabling clause of 1979 , for instance -, culminating in the understanding of the said article of the Uruguay round (1993), do not shed much light on the formal institutional structure that must shape the schemes towards a free trade zone or a customs union between two or more contracting partners. Nowhere in the agreements that establish the rules and disciplines of the multilateral trade system is there any disposition regarding concrete arrangement as it regards its institutional framework. 
Historically, there is only one example of a supranational endeavor aiming to integrate countries that are legally bound by the rules of multilateral trade: the current European Union, which emerged after a very long process of strategic steps pointing to the reciprocal "disarming" between the most important countries in the region. One cannot forget that the real factors behind the decision taken in 1951 and in 1957 were of a geopolitical nature - to prevent, to state it bluntly, new wars on the continent - and that the main decisions were taken, and are always taken, on the basis of a intergovernmental understanding, not a supranational action. Indeed, when someone proclaims the alleged virtues of the supranational model - which overcomes the usual resistance to changes in domestic regimes deriving from the sovereignty principle - one cannot overlook the fact that the main operating levers of any major decision are always kept within the control of national governments. The High Authority of the Coal and Steel Community, and the Commission of the European Community, later Union, are theoretically independent from national governments, but it is always these governments that set the pace and the nature of the major strategic decisions being adopted by the political (Council) and technical bodies.

In other words, the unique and sole supranational model in force in the domain of integration experiments has to adapt itself - when not simply submitting to it - to the reality of intergovernmental power, in a world dominated, since Westphalia, by the most important principle of the nation states, that is, national sovereignty. It is not surprising, then, that the vast majority of integration schemes existing in the world, loosely monitored by the WTO, are framed under various forms of intergovernmental arrangements, and are not, more directly, based on simple forms of preferential trade agreements, devoid of any complex system of institutional decision-making structure. In fact, some ninety percent of the integration agreements registered in the WTO are in the form of preferential trade arrangements or free trade zones, exempting themselves of any kind of formal manage- 
ment body, or even a physical location or a bureaucracy; in most cases, they consist only of working groups or technical committees and an ad hoc dispute settlements mechanism.

It would be unwise, or, saying it plainly, totally wrong, to pretend that those "light" arrangements have failed to accomplish their stated objective, that is, to liberalize and expand trade and other forms of exchanges among their constituent parties, which were, precisely, their primary purposes. They perform what they were devised to do: the dismantling of barriers to trade, facilitation of business transactions, and stimulation of all kinds of exchanges, joint ventures and direct investments between partners. Chile and Mexico, to cite the two most prominent promoters of free trade agreements in Latin America, have done precisely that with all types of partners from all continents; NAFTA, in the same movement, works as expected, without any of the entanglements of the "gothic cathedral" erected in Brussels, and elsewhere, with its thousands of Eurocrats, and jungle of rulings and Community decrees, with all the transaction costs involved in the cumbersome bureaucracy of the European model, which has a big budget for its own functioning .

Summing up this somewhat abstract discussion over the machinery of the process of integration, there is no real opposition or exclusive alternatives between the supranational and the intergovernmental modes of institutional organization, provided that each approach is able to accomplish what it was projected to do: it's the function, rather than the form, that has to be favored in the analysis of the concrete cases.

\section{Latin America in the Crucible of Integration Possibilities: Recent Cases}

In recent times, various Latin American countries - starting with Brazil and Venezuela - took some initiatives in establishing, albeit in more of a political than economic manner, new institutions, purpose- 
fully for the integration of a variety of members in the region. In those agreements - beginning with the Brazilian proposal of a Community of South American Nations, signed in December 2004, in Cusco, Peru, which was later replaced by a union, UNASUR, as suggested by Venezuela's Hugo Chávez - there are no precise instruments or explicit objectives for the economic integration of member countries, that is, trade liberalization schemes, formal mechanisms for the reciprocal opening up of economies, or even schedules or time frames around which to manage the stated goal of "integrating" the member countries. They are inspired by vague political declarations as well as dominated by an excessive exposure of the leaders, which produces the effect of promoting an infinite succession of summit meetings with the presidents, and formal conferences with ministers, and too little actual hard technical work around concrete objectives. The rhetoric embedded in the presidential declarations - as long as practically unworkable - usually surpasses the needed pragmatic task of fixing concrete goals for the stated objective of integration.

The question is not exactly a lack of vision about regional integration as it is a peculiar world vision regarding the specific kind of integration that some of those leaders intend to achieve. In 2005, for instance, Argentina's Kirchner, Brazil's Lula and Venezuela's Chávez were successful in imploding the U.S. lead project of an all American (that is, Hemispheric) Free Trade Agreement, arguing about the huge asymmetries between the Big Brother of the North and the Small Brothers in the South. Lula had stated, as early as 2002 (before becoming president), that this agreement would not be a treaty of integration, but one of "annexation". In fact, they had nothing to propose in place of the FTAA, and soon thereafter the United States was negotiating free trade bilateral agreements with like-minded countries, which explicitly excluded the three big opponents of the market access arrangements; in a few years after the "sinking" of the FTAA, a network of free trade agreements had been established among the U.S. and some 
major partners in the region, including Chile, Peru, Colombia, Central American and Caribbean countries.

A little time later, Hugo Chavez proposed, and quickly implemented with Cuba and Bolivia, a Bolivarian Alliance of the People, ALBA, with the proclaimed goal of establishing "real integration" among them. In fact, the scheme was dominated by Chávez's petrodollars and limited flows of managed trade among the state companies of those countries, without any concrete integration of their productive sectors (of which in Cuba there were none in the private sector, and in Venezuela they were nationalized and totally inefficient). Even if UNASUR comprises many important market economies of the continent, the leading impetus to the alleged "integration" comes from state controlled projects, with all the problems connected with totally different regulatory systems and the many restrictions for non-national undertakings in the selected areas of cooperation. In fact, the essential governmental nature of the many proposed endeavors (lots of them, on paper) means that most of the possible interfaces for integration are dealt with on an ad hoc basis, under bilateral schemes of cooperation, not exempt from rules for government procurement, quantitative restrictions and unilateral safeguards. Even in a more profound integration process such as MERCOSUR, allegedly centered in commerce, the intensity of intra-bloc trade has been diminishing, instead of growing, thanks to the many protectionist measures being introduced by member countries, especially Argentina. What is to be expected, then, from shallow experiments, with very narrow policy opportunities for private enterprises, in UNASUR or ALBA? Again and again, national sovereignty concerns explain most of the obstacles being erected in the various "integration" schemes.

But it is not all rhetoric and vague political ideas, made out of thin air: in the case of most "liberal" countries of the continent, a new pragmatic scheme of integration was created more recently: the Pacific Alliance, reuniting Mexico, Colombia, Peru and Chile, which, by the 
way, are the sole countries in Latin America that have already free trade agreements with the United States, and with many other important partners, including the EU, China, and other Asia Pacific countries. With little appeal to rhetoric and a clear objective vision about trade and investments, they stated the goal of achieving free trade among themselves within a fixed time frame, and integrating themselves in the vast convergence of economic initiatives being discussed in this enormous region, which should supplant the North Atlantic geo-economy in the near future. Already the Pacific Alliance has attracted the two small members of MERCOSUR, Paraguay and Uruguay, while causing concerns among its two major partners. MERCOSUR is being derided even by Brazilian entrepreneurs and some important political leaders as a fading bloc, which is hampering, instead of helping, Brazil's integration into the world.

\section{National Sovereignty: The Hidden Specter of Latin American Integration}

Of course, regional integration is being endangered not only by those old fears of losing the capacity of devising autonomous choices regarding their public policies, but mostly by the inability of Latin American countries to respect their own commitments in the signed agreements promising a bright common future under ambitious regional integration schemes. In fact, every agreement in Latin America is comprehensive, all encompassing, pervasive ... and not feasible.

In addition to the three most important priorities of Lula's foreign policy, stated at his inaugural speech in January 2003 - that is, a permanent chair at the UN Security Council, the expansion and the strengthening of MERCOSUR, and the conclusion of multilateral trade negotiations in the WTO - a guiding principle had to be upheld at all costs: the defense of national sovereignty, as the president complained that Brazil, according to him, was too submissive to foreign po- 
wers (either the U.S., IMF, Wall Street, and the like). The first endeavor, to be sure, was the implosion of the FTAA, after which Lula's diplomacy started to create new organizations and institutions with the purpose of serving exclusively Latin American or South American countries, at the exclusion of the "empire", or the hegemonic powers to the north. MERCOSUR was declared to be too commercial, and, consequently, new "social" and "political" clothes were sewed to fit the new mold drawn by PT's ideologues. A Parliament, a Social Institute, and many other bodies deviating from the spirit (and the letter) of the Asuncion treaty were put in place, so as to compensate for the lack of progress in the reciprocal opening up of economies and trade liberalization.

Brazil was actively entrepreneurial in all those endeavors, aiming to establish a kind of "regional leadership" which, in fact, was never accepted by the neighboring countries. The proposed new forums submitted to the regional partners by Brazil's diplomacy have served much more the so-called Bolivarian countries than its own strategic vision for the continent. Nevertheless, big Brazilian private companies as well as some state enterprises made new inroads into the economies of South American neighbors, even if it was impossible to foresee some big frustrations (the nationalization of Petrobras assets in Bolivia, for instance, was not predicted, and neither were the obstacles the company encountered in Argentina and Venezuela). Again, the main factor behind those hindrances to Brazil's penetration into the economy of those countries is the same old idiosyncrasy of Latin America: national sovereignty, and the fear that "external powers" will come in and end up controlling some sectors, or entire areas, of the country.

By and large, when the new leaders, groups or initiatives pretend to build "regional integration" in Latin America, in most of the cases, the involved leadership is really (or merely) thinking about consultation and coordination of projects for political cooperation among the 
countries, not the same process of deep economic integration as engaged in Western Europe since the 1950s. And, in extremely rare opportunities, they conceive those projects as rising above the strict intergovernmental cooperation schemes, that is, the whole process has to be directly controlled by their national bureaucracies (or by themselves, as revealed by the multitude of summits being held in the region). The last thing they admit to is weakening the sacred wall of national sovereignty, short of being accused, domestically, of surrendering some vital interest to a foreign country.

This is the world vision and the core principle of the juridical universe that unites, in the same conceptual framework, the politicians and people from academia in most Latin American countries. Even, in an hypothetical exercise of virtual history, if it could be different from that Weltanschauung, with countries or leaders disposed to cede sovereignty in the name of a real integration project, and agreeing to some sort of supranational scheme to lead that process, it is highly doubtful that an experiment of this kind could be more successful and achieve its objectives than the actual intergovernmental organizations in force in the region: ALALC (1960), the Andean Group (1969), ALADI (1980), MERCOSUR (1991), ALBA (2006), or UNASUR (2010). Not a single one of those different organizations has effectively attained the objectives and formally written goals and statements of their respective original treaties.

On the contrary: had any one of them enforced supranational rules over national bureaucracies, and against domestic economic constituencies, failure would have come earlier, and in a more outrageous manner, with a total lack of credibility being exposed to the outside world, than the actual course of the events which was a slow and gradual slump into a practical irrelevance. The Andean Group was the only one to try to copy some of the European institutions, including a "commission" (the Junta, in Lima), and a "tribunal" (in Bogotá), both inspired by the supranational model, and both a complete failu- 
re; the exit of Chile from the group, in 1975, is due to the incompatibility between the new receptivity to foreign investments in the "neoliberal" country and the Investments Code of the Andean group, compulsory for any of its members. Proclaiming the objective of turning itself into a common market - even in a more explicit version than the implicit goal of MERCOSUR -, the Andean Group, now Andean Community, never made it to a unified customs union, which MERCOSUR already pretended to be (without really complying with the formal requirements of such a scheme). ${ }^{6}$

That brings to the fore the discussion of the real source of the failure of the integration processes in Latin America, which is only in part due to the adherence of most countries to a narrow concept of national sovereignty. This principle is usually equated with the refusal of any kind of supranational institution to manage those processes and, conversely, a strict faithfulness of the countries in the intergovernmental model. In fact, the question lies in the lack of disposition of member countries in any process in complying with the requirements of the signed agreements, as well as to enforce domestically the decisions they adopt in their diplomatic conferences. Certain countries, in fact, behave worse than that: they openly affront the spirit and the writings of the constitutive treaties, by adopting measures and laws explicitly in violation of their previous commitments, which is only one aspect of the little respect some governments pay to the legal order in their own countries. An assessment of the cases being appealed to the Supreme Court in certain countries would probably reveal a high proportion of infringements to the national legal order originating in the very actions (or the omissions) of the governments elected to enforce the rule of law.

Finally, if there must be a choice between institutional models that should help the process of integration, with a distinctively superior quality - in practical terms, not under a theoretical approach, which is not really relevant for real purposes -, that one should be the most fle- 
xible one, on operational grounds, in order to give member countries real latitude of action to attain the main objectives of the process. Again, the form should not determine the function, but the contrary: the instrument should be adapted to the task to be performed. In the real world, it must be for this very reason that preferential arrangements, and free trade agreements are the most likely to attain their stated objectives. Contrariwise, in the ideal world of the "integration engineers", over elaborated schemes, drawn by the pens and computers of cabinet economists, are most likely to fail in delivering what they promise. Again and again: it is not the institutional envelope of the process that should determine the true contents of the integration; map the terrain first, build the camp later on, if possible.

A theoretically perfect institutional structure can be defeated by the crude test of economic reality, as the many experiments in economic integration in Latin America have proved again and again. On the other hand, an excessively rigid scheme, such as the one existing in the EU, requires a very high degree of cohesion among member countries, as well as great uniformity in national sectorial policies and legislative homogeneity, conditions that are not easily attainable in any economic process, even more so in the current conditions of the global economic interdependence.

An old economic law - if one can recall the simple lessons of the past - posits the social division of work and the smooth functioning of the markets, as the ideal conditions for prosperity and well-being, against former mercantilist-driven policies for national power and political glory. The dynamics of contemporary interdependence is being built upon the difference of capacities and the intermeddling of national endowments - that is, the free interaction of productive factors among countries, in a situation of an almost free functioning of the markets (with a little help of some intergovernmental economic organizations, but not always). In any case, this kind of scenario is a better prescription for a prosperous world, than a committee of bureaucrats 
taking decisions on behalf of the many millions of citizens who create the real riches in any society. Most Latin American countries are very far from this kind of economic concept, but in due course they will have to join the avant-garde battalion of the most successful countries. It will take some time, as even Europe is learning from the current economic stagnation; rationality, and the capacity to effectuate comparisons are still two of the distinctive characteristics of men, of every human thinker.

\section{Notes}

1. For a brief presentation of the "Calvo Doctrine", see Encyclopedia Britannica Online, available at: <http://www.britannica.com/EBchecked/topic/90348/ Calvo-Doctrine>. Accessed on: Sept. 27th, 2013.

2. A quite honest description of the new principle is presented by the Office of the Historian of the Department of State, "Roosevelt Corollary to the Monroe Doctrine, 1904". Available at: <http://history.state.gov/milestones/18991913/RooseveltandMonroeDoctrine>. Accessed on: Sept. 2013.

3. See Burns (1966).

4. See the full text of this convention at the Avalon Project of Yale Law School. Available at: <http://avalon.law.yale.edu/20th_century/hague072.asp>.

5. See Medeiros (2006).

6. For some developments in this same subject, see Almeida (2013, p. 51-69).

\section{References}

ALMEIDA, Paulo Roberto de. O Mercosul no contexto da integração regional latino-americana. In: RIBEIRO, E. de S. (Coord.). Direito do Mercosul. Curitiba: Editora Appris, 2013. 
BURNS, E. Bradford. The Unwritten Alliance: Rio Branco and Brazilian-American Relations. New York: Columbia University Press, 1966.

CALVO, Carlos. Le Droit international théorique et pratique, précédé d'un exposé historique des progrès de la science du droit des gens. Paris: Durand et Pedone-Lauriel, 1868.

MEDEIROS, Antonio Paulo Cachapuz de. Special Meeting of the Permanent Council Marking the Centennial of the Inter-American Juridical Committee (CJI). Document CP/INF 5326/06, March 29th, 2006.

MESSAGE from the Brazilian president to the Congress, May 3, 1908, regarding the conventions signed at the II Peace Conference. In: CÂMARA DOS DEPUTADOS. Mensagens Presidenciais, 1890-1910. Brasília: Centro de Documentação e Informação da CD, 1978.

TRINDADE, Antonio Augusto Cançado. Repertório da prática brasileira do direito internacional público: período 1899-1918. Brasília: Fundação Alexandre de Gusmão, 1986.

\section{Abstract}

\section{Sovereignty and Regional Integration in Latin America: A Political Conundrum?}

There is an inherent contradiction between the regional integration projects in Latin America, albeit rhetorically conducted, and the staunch defense by most countries of their national sovereignty, which restricts and opposes many liberalization mechanisms implicit in, and necessary to, the integration processes, based on the rendition of sovereignty in some areas of economic relevance, including, and especially, trade and industrial policies, as well as other sectorial measures. The dilemma is historically compounded by a juridical tradition that places the retraction into an introverted version of the sovereignty principle into the context of conceptual elaborations well known in the international law, such as Calvo doctrine and the Drago principle. Brazil is one of the most resolute promoters of the national sovereignty principle among Latin American countries, clearly expressed in its constitutional chart and foreign policy stances, since the Second Hague peace conference of 1907. Other Latin 


\section{Sovereignty and Regional Integration in Latin}

America: A Political Conundrum?

American countries, mainly in Central America and the Caribbean, are much more motivated by real concerns over recurrent United States interventionism in the regional, in some cases by military means. This framework has somewhat infringed on integration projects, which is also hindered by economic nationalism and state interventionism.

Keywords: Regional Integration - National Sovereignty - Latin America Decision-Making Institutions - Political Obstacles 